\title{
Youth Networks' Advances Toward the Sustainable Development Goals During the COVID-19 Pandemic
}

\author{
Kevin Barber ${ }^{1}$ and Mohammed A. Mostajo-Radji ${ }^{2,3,4 *}$ \\ ${ }^{1}$ The Rockefeller University, New York, NY, United States, ${ }^{2}$ Embassy of Science, Technology and Innovation, Ministry of \\ Foreign Affairs of Bolivia, La Paz, Bolivia, ${ }^{3}$ Permanent Mission of Bolivia to the United Nations, New York, NY, United States, \\ ${ }^{4}$ Clubes de Ciencia Bolivia Foundation, Santa Cruz de la Sierra, Bolivia
}

Keywords: science diplomacy, United Nations, non-state actors (NSAs), sustainable development goals-SDGs, youth networks, COVID-19

\section{INTRODUCTION}

The emergence of the COVID-19 pandemic, a disease caused by novel coronavirus SARS-CoV-2 (Zhu et al., 2020), has presented major challenges to international public health systems. As new data surrounding the epidemiology of the disease continues to emerge, policy recommendations made by institutions such as the World Health Organization have been continually modified and inconsistently applied by national and local governments. For instance, in an effort to contain the initial spread of the disease internationally and reduce the rate of transmission domestically, early affected countries implemented policies to restrict travel and limit the social contact of their citizens (Acosta and Nestore, 2020; Anderson et al., 2020). While these strategies have been

\section{OPEN ACCESS}

Edited by:

Victoria Ann Newsom Olympic College, United States

Reviewed by:

Ganiu Oladega Okunnu, Crescent University, Nigeria

${ }^{*}$ Correspondence: Mohammed A. Mostajo-Rad ji mmostajo@rree.gob.bo

Specialty section:

This article was submitted to Political Communication and Society, a section of the journal Frontiers in Sociology

Received: 30 July 2020 Accepted: 07 October 2020 Published: 29 October 2020

Citation:

Barber $K$ and Mostajo-Radji MA (2020) Youth Networks' Advances Toward the Sustainable Development Goals During the COVID-19

Pandemic. Front. Sociol. 5:589539. doi: 10.3389/fsoc.2020.589539 found to be effective at reducing the rates of new cases and minimizing the resulting strain to national healthcare systems (Chinazzi et al., 2020), global spread of the disease proved to be unavoidable. Yet specific responses enacted by national governments to mitigate the impact the pandemic would have on their society have varied (Anderson et al., 2020), and in cases, seemingly come in contradiction to one another. Inherent to these discrepancies appears to be a concern between limiting the health and mortality repercussions of the pandemic, opposed with reducing the economic impact associated with commercial and social restraint (Sheridan et al., 2020). The fractured international approach has highlighted the limitations established forms of governance have in agreeing upon and implementing legitimate measures of resolution during a rapidly evolving global pandemic, and how these limitations culminate in serious strains to international public relations.

Recently, the concept of transnational youth networks (TYNs) has emerged as a flexible solution to many of the obstacles faced by international and domestic governance (Acosta et al., 2020). Defined broadly as a cross-disciplinary professional group with members under the age of 40 and selected based on a competitive process that analyzes professional achievements, the hallmarks of TYNs maintain a versatile set of descriptions. These include the selection of members based on the merit of professional achievements, empowerment of decision-making capabilities toward achieving a defined goal, and the application of unique experiential knowledge of individual members (Acosta et al., 2020). Prior to the emergence of the COVID-19 pandemic, organization of TYNs was proposed as a means of driving forward public diplomacy, particularly in relation to the United Nations Sustainable Development Goals (SDG) agenda (Acosta et al., 2020). At the present moment, the preeminent objectives of the SDG agenda have been put in jeopardy by the unfolding pandemic (Naidoo and Fisher, 2020). Most relevantly, the objective of ensuring the health and well-being of global citizens through efficient funding and access to healthcare systems, along with increased sanitation and hygiene (Filho et al., 2020; Sustainable Development Goals, 2020). 
While the WHO and its affiliated partners have been paramount in providing recommendations to national governments' response to the pandemic, groups tantamount to TYNs have ascended to resolve many of the deficiencies left by broader governing bodies. Here we will provide an overview of exemplary solutions designed by these groups and present support for the continued backing of these types of networks as a mechanism to engage international crises. Though these groups do not fall definitively within our working definition of TYNs, we will argue that they contribute useful models of youth empowerment, nonetheless.

\section{YOUTH NETWORKS AND THE COVID-19 PANDEMIC}

Underlying the initial decision made by many national governments to enact extensive quarantining measures on citizens was a concern of overwhelming health care systems with growing rates of COVID-19 patient numbers. Accompanying predictions of shortages of health care system resources was an anticipation of a lack of available personal protective equipment (PPE) for health care workers. In the United States, while health care systems struggle to correspond with the national government for these supplies, a decentralized source of supply chain management was constructed by a coalition of young volunteers. To date, the $\mathrm{C} 19$ Coalition reports to have successfully supplied over 100 million PPE units to health care systems across the US and has formed a working collaboration with the National Governors Association, connecting governmental bodies with public and private organizations (Levy, 2020a). Additionally, creative solutions to develop new forms of PPE have been organized under the banner of \#HackThePandemic and unified by hackthepandemic.org (Mensley, 2020). This organization allows volunteers and researchers across the globe access to $3 \mathrm{D}$ printable mask designs, as well as the ability to contribute large scale manufacturing capabilities of supplies and computing power aimed at the pursuit of understanding the disease through simulations of protein folding. The capability to $3 \mathrm{D}$ print effective mask designs has been embraced by high school and university students across the United States, including those in initially hard-hit cities such as New York and Seattle (Reid, 2020; Schlosser, 2020; Siegal, 2020). These techniques have been transferred and reproduced in other countries, particularly in the developing world (Tendencias El Tiempo, 2020). These initiatives provide outstanding examples of how the youth can adapt new technologies to contribute to solving dilemmas currently facing healthcare systems.

Along with shortages of PPE, a looming concern for international healthcare systems remains a lack of available ventilators, an essential piece of equipment for the treatment of critically ill patients (Truog et al., 2020). These inventory shortages have placed major strains on international diplomacy, as countries have exercised restrictions of the transport of ventilators across borders, and in some cases gone as far as resorting to the confiscation of other countries' ventilators during international transit (Kamdar, 2020). The developing world remains most vulnerable to these shortages (Breevoort et al.,
2020), inspiring innovative design solutions for low cost and readily transportable ventilators from youth teams. These include ventures by US university students (Levy, 2020b; Rusch, 2020), as well as a team of young engineers from India, a country with an especially sparse ventilator inventory compared to the domestic population (Biswas, 2020). Additionally, a large review of these types of open source designs has been compiled for future adaption (Pearce, 2020). One of the most comprehensive networks involved in broad scale coordination between globally distributed volunteer groups working to design and produce PPE and medical supplies has been the Open Source Medical Supplies. This organization reports a current record of statistics related to the above venture, including the number of countries actively involved in local response efforts and the total amount of supplies that have been successfully delivered by the global community (Open Source Medical Supplies). Continuing to increase the supply and universal accessibility of ventilators will not only aid the treatment capabilities of underserved health care systems but may also begin to alleviate international diplomacy tensions that result from global medical equipment shortages. Of particular interest, is the focus youth networks have made on advocating for the attention to how regional aspects of the developing world pose specific challenges to coping with a spreading pandemic. For instance, populations living in high altitude regions such as Ethiopia, Ecuador, Bolivia, and Tibet, are sensitive to environmental conditions and physiological adaptations that influence the effectiveness of common ventilator design (Breevoort et al., 2020). Given the limited influence these regions have in the development of traditional health care equipment, special considerations will be necessary to design and supply ventilators capable of functioning effectively for high altitude populations.

Perhaps most at risk of suffering from a lack of specialized intervention in regards to the COVID-19 pandemic are refugee populations and people living in war zones (Jahanshahi et al., 2020). Given the poverty of health care related infrastructure, coupled with increased rates of underlying medical conditions and high population densities often found in refugee camps, the risk of infection within these zones has been a notably difficult problem for traditional governmental systems to address. To help facilitate screening capabilities of health care practitioners serving refugee populations, students at Harvard University have developed a software solution for the efficient collection and sharing of patient data (Parks, 2020). This technology has now become widely available and adapted to the needs of health practitioners within refugee camps across the globe. This development can be viewed as a pivotal first step to mitigating the severity of the pandemic on displaced populations, but more measures will clearly be needed to resolve the special vulnerability of these groups.

\section{ADVANCING THE SUSTAINABLE DEVELOPMENT GOALS AGENDA THROUGH YOUTH NETWORKS}

In 2015, the United Nations put forward the SDG agenda as a blueprint to achieve a better and more sustainable future for all 
by 2030 (Joshi et al., 2015). While received with enthusiasm by most member States, the COVID-19 pandemic can potentially delay and even jeopardize the implementation of many of those goals (Naidoo and Fisher, 2020). Indeed, several analyses have revealed that the pandemic has worsened inequalities throughout the world and active interventions from governments are needed to address these issues (Ashford et al., 2020). To assist these needs, UNICEF has been at the forefront of organizing remote networks of youth volunteers inspired to rise to challenges specific to their communities (Hawke, 2020). The formation of this network, headed entirely by youth volunteers, was able to quickly progress through the stages of volunteer recruitment, identification of specific challenges, and response of clear-cut actions. This included initiatives that are aimed at safeguarding the mental health of the youth through access to online psychologists and creation of seed banks to be distributed for home gardening projects.

In the context of the COVID-19 pandemic, youth networks have primarily focused on SDGs 3, 4, 9, 10, and 17. Namely: Good health and well-being; quality education; industry, innovation and infrastructure; reduced inequalities; and partnerships for the goals. Yet, it is important to notice that SDGs are indeed interlinked and the development of one goal strengths the development of others (Dawes, 2020). Dynamic mathematical models have indeed shown that efforts to address goals 4-16 have a direct impact on goal 1, elimination of poverty (Dawes, 2020). As such providing access to healthcare technology has an impact on economic projections (Mahler et al., 2020). Using the examples pinpointed in this manuscript, one can see that 3D printing of PPE and ventilators, have not only addressed SDG 3, but inspired other regions in the world to adopt these technologies (addressing SDGs 4 and 9), consequently reducing inequality (SDG 10) and poverty (SDG 1).

\section{OBSTACLES FACED BY YOUTH NETWORKS IN GAINING GOVERNMENTAL SUPPORT}

Due to the characteristic of being non-state actors, youth networks are often left behind in policy and decision making (Carosso et al., 2019a). Indeed, one of the most common negative perceptions of young entrepreneurs and technology activists is the lack of governmental interest and support for their initiatives (Saucedo-Bendek et al., 2020).

The COVID-19 pandemic has further highlighted some of these issues. For instance, there is an overall lack for governmental-sponsored grants directed toward young, independent entrepreneurs and volunteer groups (Young and Grinsfelder, 2011; Legg, 2020; Naude, 2020). Even when financing is obtained, the youth usually has to face additional struggles, including difficulties in obtaining quality certifications for their products. As an example, the United States Food and Drug Administration (FDA) has been overly cautious in approving the use of $3 \mathrm{D}$ printed PPE and medical equipment (US Food \& Drug Administration, 2020), granting emergency approval to only a handful of organizations (Rodrigo, 2020). Indeed, the majority of FDA COVID-19 actions have focused on relaxing their enforcement guidelines, rather than actively overseeing the development and approving the use of materials and equipment created by youth networks (Flanagan and Ballard, 2020). A similar situation, though to varying degrees, has been observed in other parts of the world, including the European Union (Gierthmuehlen et al., 2020) and the United Kingdom (Emanuel et al., 2020). While aiming to protect the public, these procedures have produced unintended consequences. Specifically, COVID-19 emergency donations and loans provided by multinational organizations such as the United Nations Development Programme, the World Bank and the Interamerican Development Bank often require governments to spend these resources on materials and equipment that are certified by the FDA or the European Union (Ferreira and Mostajo-Radji, 2020). Notable cases are beginning to show the potential of overcoming these sorts of obstacles. For instance, the Bolivian government has worked together with young entrepreneurs to provide local certifications that allows them commercialize 3D printed ventilators in the local market (Los Tiempos Digital, 2020). Similarly, in Colombia, private and university-based ventilators printing projects have gained support from the national medical device regulatory body to begin human trials (Zimmer, 2020). Surmounting governmental regulations currently presents a major impediment to the employment of supplies designed by non-governmental groups and these requirements, in return, hamper governments from supporting initiatives developed by youth networks (Condori, 2020).

\section{CONCLUSIONS}

The development of youth networks capable of identifying and undertaking challenges specific to their communities will not only drive forward solutions related directly to their objectives, but consequently advance a common global agenda, independently of direct governmental support (Carosso et al., 2019b). Altogether, the contributions youth networks have made toward addressing aspects of the current pandemic provide a glimpse into the power of non-traditional forms of public health intervention. The examples listed here should serve as models of the benefit of forming such networks, and continued development of youth networks motivated to solve global issues and advance the United Nations SDGs should be kept in focus.

\section{AUTHOR CONTRIBUTIONS}

All authors listed have made a substantial, direct and intellectual contribution to the work, and approved it for publication.

\section{ACKNOWLEDGMENTS}

We would like to thank Sebastian Torres Montoya for insightful comments on this manuscript. 


\section{REFERENCES}

Acosta, M., and Nestore, M. (2020). Comparing public policy implementation in Taiwan and Vietnam in the early stages of the COVID-19 outbreak: a review. SocArXiv. doi: 10.31235/osf.io/69hqx

Acosta, M., Szlamka, Z., and Mostajo-Radji, M. A. (2020). Transnational youth networks: an evolving form of public diplomacy to accelerate the sustainable development goals. SocArXiv. doi: 10.31235/osf.io/8247s

Anderson, R. M., Heesterbeek, H., Klinkenberg, D., and Hollingsworth, T. D. (2020). How will country-based mitigation measures influence the course of the COVID-19 epidemic? Lancet 395, 931-934. doi: 10.1016/S0140-6736(20)30567-5

Ashford, N. A., Hall, R. P., Arango-Quiroga, J., Metaxas, K. A., and Showalter, A. (2020). Addressing inequality: the first step beyond COVID-19 and towards sustainability. Sustainability 12:5404. doi: 10.3390/su12135404

Biswas, S. (2020). Coronavirus: India's race to build a low-cost ventilator to save COVID-19 patients. BBC News. Available online at: https://www.bbc.com/ news/world-asia-india- 52106565 (accessed July 30, 2020).

Breevoort, A., Carosso, G. A., and Mostajo-Radji, M. A. (2020). High-altitude populations need special considerations for COVID-19. Nat. Commun. 11:3280. doi: 10.1038/s41467-020-17131-6

Carosso, G. A., Ferreira, L. M. R., and Mostajo-Radji, M. A. (2019a). Developing brains, developing nations: can scientists be effective non-state diplomats? Front. Educ. 4:95. doi: 10.3389/feduc.2019.00095

Carosso, G. A., Ferreira, L. M. R., and Mostajo-Radji, M. A. (2019b). Scientists as non-state actors of public diplomacy. Nat. Hum. Behav. 3, 1129-1130. doi: 10.1038/s41562-019-0716-1

Chinazzi, M., Davis, J. T., Ajelli, M., Gioannini, C., Litvinova, M., Merler, S., et al. (2020). The effect of travel restrictions on the spread of the 2019 novel coronavirus (COVID-19) outbreak. Science 368, 395-400. doi: $10.1126 /$ science.aba9757

Condori, B. (2020). A 5 meses de presentar respiradores, Mambu espera autorización del Gobierno. Opinion Bolivia. Available online at: https://www. opinion.com.bo/articulo/pais/5-meses-presentar-respiradores-ambu-esperaautorizacion-gobierno/20200817131252782731.html (accessed September 25, 2020).

Dawes, J. H. P. (2020). Are the sustainable development goals self-consistent and mutually achievable? Sus. Dev. 28, 101-117. doi: 10.1002/sd.1975

Emanuel, E. J., Persad, G., Upshur, R., Thome, B., Parker, M., Glickman, A., et al. (2020). Fair allocation of scarce medical resources in the time of COVID 19. N. Engl. J. Med. 382, 2049-2055. doi: 10.1056/NEJMsb2005114

Ferreira, L. M. R., and Mostajo-Radji, M. A. (2020). Plasma-based COVID-19 treatments in low- and middle-income nations pose a high risk of an HIV epidemic. npj Vaccines 5:58. doi: 10.1038/s41541-020-0209-2

Filho, W. L., Brandli, L. L., Salvia, A. L., Rayman-Bacchus, L., and Platje, J. (2020). COVID-19 and the UN Sustainable development goals: threat to solidarity or an opportunity? Sustainability 12:5343. doi: 10.3390/su12135343

Flanagan, S. T., and Ballard, D. H. (2020). 3D printed face shields: a community response to the COVID-19 global pandemic. Acad. Radiol. 27, 905-906. doi: 10.1016/j.acra.2020.04.020

Gierthmuehlen, M., Kuhlenkoetter, B., Parpaley, Y., Gierthmuehlen, S., Köhler, D., Dellweg, D. (2020). Evaluation and discussion of handmade face-masks and commercial diving-equipment as personal protection in pandemic scenarios. Plos ONE 15:e0237899. doi: 10.1371/journal.pone.0237899

Hawke, A. (2020). Youth volunteers rise to the challenge of COVID-19. UNICEF. Available online at: https://www.unicef.org/northmacedonia/stories/ youth-volunteers-rise-challenge-covid-19 (accessed July 30, 2020).

Jahanshahi, A. A., Gholami, H., and Mendoza, M. I. R. (2020). Sustainable development challenges in a war-torn country: perceived danger and psychological well-being. J. Public Aff. 20:e2077. doi: 10.1002/pa.2077

Joshi, D. K., Hughes, B. B., and Sisk, T. D. (2015). Improving governance for the post-2015 sustainable development goals: scenario forecasting the next 50 years. World Dev. 70, 286-302. doi: 10.1016/j.worlddev.2015.01.013

Kamdar, D. (2020). Modern day piracy and global contest for medical equipment amidst covid-19 pandemic. News18. Available online at: https://www.news18. $\mathrm{com} /$ news/opinion/modern-day-piracy-and-global-contest-for-medicalequipment-amidst-covid-19-pandemic-2630129.html (accessed July 30, 2020).
Legg, H. (2020). Rural development project uses 3D printing in fight against COVID-19 spread. U.S. Department of Agriculture. Avaiable online at: https.// www.usda.gov/media/blog/2020/04/01/rural-development-project-uses-3dprinting-fight-against-covid-19-spread (accessed September 25, 2020).

Levy, N. (2020b). Solving the ventilator shortage with windshield wiper parts. UT News. Available online at: https://news.utexas.edu/2020/04/01/solving- theventilator-shortage-with-windshield-wiper-parts/ (accessed July 30, 2020).

Levy, R. (2020a). Tech entrepreneurs form coalition to take on sourcing coronavirus supplies. The Wall Street Journal. Available online at: https://www. wsj.com/articles/tech-entrepreneurs-form-coalition-to-take- on-sourcingcoronavirus-supplies-11588247752 (accessed July 30, 2020).

Los Tiempos Digital (2020). Mambu recibe certificado técnico de aprobación de Agemed. Available online at: https:/www.lostiempos.com/actualidad/ cochabamba/20200914/mambu-recibe-certificado-tecnico-aprobacionagemed (accessed September 27, 2020).

Mahler, D. G., Lakner, C., Aguilar, R. A. C., and Wu, H. (2020). Updated estimates of the impact of COVID-19 on global poverty. World Bank Blogs. Available online at: https://blogs.worldbank.org/opendata/updated-estimatesimpact-covid-19-global-poverty (accessed July 30, 2020).

Mensley, M. (2020). Coronavirus crisis: 3D printing community responds. All3DP. Available online at: https://all3dp.com/1/coronavirus-covid-19-sarscov-2-3d-printing/ (accessed July 30, 2020).

Naidoo, R., and Fisher, B. (2020). Reset sustainable development goals for a pandemic world. Nature 583, 198-201. doi: 10.1038/d41586-02001999-x

Naude, W. (2020). Entrepreneurial recovery from COVID-19: decentralization, democratization, demand, distribution, and demography. IZA Discussion Paper 13436. Available online at: https://ssrn.com/abstract=3643200 (acessed September 25, 2020).

Open Source Medical Supplies (2020). Available online at: https:// opensourcemedicalsupplies.org/impact/ (accessed September $27,2020)$.

Parks, A. (2020). Brothers create screening tool for refugee populations. The Harvard Gazette. Available online at: https://news.harvard.edu/ gazette/story/2020/05/brothers-deploy-covid-19-screening-tool-forrefugee-populations/?fbclid=IwAR0qyCF7Lr0x0VEzKN27ls7LEYloPF0mIBNwh1Wd-2uXotY2SHBCBU4WFw (accessed July 30, 2020).

Pearce, J. M. (2020). A review of open source ventilators for COVID-19 and future pandemics [version 2; peer review: 3 approved]. F1000Research 9:218. doi: 10.12688/f1000research.22942.2

Reid, D. (2020). Students make 3D printed masks to help battle coronavirus. Sacramento State News. Available online at: https://www.csus.edu/news/ articles/2020/4/6/Students-create-3D-printed-masks-for-local-hospital.shtml (accessed July 30, 2020).

Rodrigo, C. M. (2020). 3D printing faces hurdles in coronavirus response. The Hills Available online at: https://thehill.com/policy/technology/491681-3d-printingfaces-hurdles-in-coronavirus-response (accessed September 25, 2020).

Rusch, E. (2020). As COVID-19 spreads around the world, mines student designs low-cost ventilator. Mines Newsroom. Available online at: https://www. minesnewsroom.com/news/covid-19-spreads-around-world-mines-studentdesigns-low-cost-ventilator (accessed July 30, 2020).

Saucedo-Bendek, O., Ewel, S., and Roman-Roig, F. J. (2020). Entrepreneurs' perception toward international cooperation and government programs concerning entrepreneurship. Front. Educ. 5:57. doi: 10.3389/feduc.2020.00057

Schlosser, K. (2020). With high school's 3D printers in his house, student runs mask production line for seattle-area hospitals. GeekWire. Available online at: https://www.geekwire.com/2020/high-schools-3d-printers-house-studentruns-mask-production-line-seattle-area-hospitals (accessed July 30, 2020).

Sheridan, A., Andersen, A. L., Hansen, T., and Johannesen, N. (2020). Social distancing laws cause only small losses of economic activity during the COVID19 pandemic in Scandinavia. Proc. Natl. Acad. Sci. U.S.A. 117, 20468-20473. doi: 10.1073/pnas.2010068117

Siegal, I. (2020). NY high school student spearheads 3D-printing initiative to get PPE to hospitals. NBC New York. Available online at: https://www. nbcnewyork.com/news/coronavirus/ny-high-school-student-spearheads-3dprinting-initiative-to-get-ppe-to-hospitals/2357930/ (accessed July 30, 2020).

Sustainable Development Goals (2020). Available online at: https:// sustainabledevelopment.un.org/?menu=1300 (accessed July 30, 2020). 
Tendencias El Tiempo (2020). Emprendedores buscan apoyo para producir máscara contra coronavirus. El Tiempo. Available online at: https://www. eltiempo.com/tecnosfera/novedades-tecnologia/novedades-tecnologia477730 (accessed July 30, 2020).

Truog, R. D., Mitchell, C., and Daley, G. Q. (2020). The toughest triageallocating ventilators in a pandemic. N. Engl. J. Med. 382, 1973-1975. doi: 10.1056/NEJMp2005689

US Food \& Drug Administration (2020). 3D printing of medical devices, accessories, components, and parts during the COVID-19 pandemic. Available online at: https://www.fda.gov/medical-devices/coronavirus-covid-19-andmedical-devices/3d-printing-medical-devices-accessories-components-andparts-during-covid-19-pandemic (accessed September 25, 2020).

Young, D. R., and Grinsfelder, M. C. (2011). Social entrepreneurship and the financing of third sector organizations. J. Public Aff. Educ. 17, 543-567. doi: $10.1080 / 15236803.2011 .12001661$

Zhu, N., Zhang, D., Wang, W., Li, X., Yang, B., Song, J., et al. (2020). A novel coronavirus from patients with pneumonia in China, 2019. N. Engl. J. Med. 382, 727-733. doi: 10.1056/NEJMoa20 01017
Zimmer, K. (2020). Colombian engineers' ventilators to be tested in COVID patients. The Scientist. Available online at: https://www.the-scientist.com/ news-opinion/colombian- engineers- ventilators-to-be-tested-in-covidpatients-67696 (accessed September 27, 2020).

Conflict of Interest: MM-R is the Bolivian Science, Technology and Innovation Ambassador.

The remaining author declares that the research was conducted in the absence of any commercial or financial relationships that could be construed as a potential conflict of interest.

Copyright (c) 2020 Barber and Mostajo-Radji. This is an open-access article distributed under the terms of the Creative Commons Attribution License (CC BY). The use, distribution or reproduction in other forums is permitted, provided the original author(s) and the copyright owner(s) are credited and that the original publication in this journal is cited, in accordance with accepted academic practice. No use, distribution or reproduction is permitted which does not comply with these terms. 